\title{
Early Permian insects from Saar-Nahe Basin of Odernheim town site, Rheinland-Pfalz in Germany (Insecta, Grylloblattida, Blattinopseida)
}

\author{
Jakub PROKOP \\ Charles University in Prague, Faculty of Science, Department of Zoology, \\ Viničná 7, CZ-128 44, Praha 2 (Czech Republic) \\ jprokop@natur.cuni.cz \\ Klaus-Dieter WEIß \\ Kelkheimerstr. 54, 65779 Fischbach (Germany) \\ elklweiss@googlemail.com \\ Roger-Paul DECHAMBRE \\ 13 boulevard Saint Marcel, F-75013 Paris (France) \\ André NEL \\ Muséum national d'Histoire naturelle, \\ CNRS UMR 7205, Entomologie, \\ case postale 50, 57 rue Cuvier, F-75231 Paris (France) \\ anel@mnhn.fr
}

KEY WORDS

Euryptilonidae,

Blattinopsidae,

Oborella,

Blania,

Early Permian,

Germany,

new synonymy, new species.
Prokop J., Weiß K.-D., Dechambre R.-P. \& Nel A. 2012. - Early Permian insects from SaarNahe Basin of Odernheim town site, Rheinland-Pfalz in Germany (Insecta, Grylloblattida, Blattinopseida). Geodiversitas 34 (2): 271-281. http://dx.doi.org/10.5252/g2012n2a2

\section{ABSTRACT}

New insect fossils from Early Permian lacustrine deposits of Odernheim town site (Saar-Nahe Basin, Rheinland-Pfalz, Germany) are attributed to Euryptilonidae (Grylloblattida) and Blattinopsidae (stem group of Dictyoptera). Oborella germanica $\mathrm{n}$. sp. is based on fore- and hindwing venation pointing out difficulties of generic separation between Blania Kukalová, 1964 and Oborella Kukalová, 1964. In addition, as first revisors of the genus Blania, we consider it as a junior synonym of Oborella, because the holotype of the type species O. matura Kukalová, 1964 is a better preserved specimen than that of Blania. We also describe another species, Oborella brauckmanni n. sp. Two Blattinopsidae are also described but not named for their incomplete state of preservation, although one is related to Glaphyrophlebia and could well correspond to a new species for its very long stem of posterior radius. 


\begin{abstract}
RÉSUMÉ
Nouveaux insectes fossiles (Insecta, Grylloblattida, Blattinopseida) du Permien inférieur du bassin de Saar-Nahe (Odernheim ville), Allemagne.

De nouveaux insectes fossiles du Permien inférieur d'Odernheim ville (bassin de Saar-Nahe, Rheinland-Pfalz, Allemagne) sont attribués aux Euryptilonidae (Grylloblattida) et aux Blattinopsidae (groupe souche des Dictyoptera). Oborella germanica n. sp. est fondée sur la nervation des ailes antérieures et postérieures, mettant en évidence les difficultés à séparer les genres Blania Kukalová, 1964 et Oborella Kukalová,

MOTS CLÉS

Euryptilonidae,

Blattinopsidae, Oborella, Blania,

Permien inférieur, Allemagne, synonymie nouvelle, espèce nouvelle. 1964. De plus, en tant que premiers réviseurs de ce genre, nous considérons le genre Blania comme un synonyme junior d'Oborella, car l'holotype de son espèce-type, O. matura Kukalová, 1964, est mieux conservé que celui de Blania. Nous décrivons aussi une autre espèce, Oborella brauckmanni n. sp. Deux Blattinopsidae sont aussi décrits mais non nommés à cause de leur état de conservation incomplet, bien que l'un d'entre eux soit proche de Glaphyrophlebia et puisse correspondre à une espèce nouvelle à cause de sa très longue partie basale de radius postérieur.
\end{abstract}

\section{INTRODUCTION}

The grylloblattid family Euryptilonidae Martynov, 1940 currently comprises 14 described genera from the Permian of Europe, Asia, and North America (Aristov 2002). These insects are mainly known after their forewing structures, the bodies and hindwings being rare and generally rather poorly preserved. Among them, the two closely similar genera Oborella Kukalová, 1964 and Blania Kukalová, 1964 are known from the Early Permian of the world famous Obora insect site (Letovice Formation, Bačov and Obora horizons, Sakmarian/Early Artinskian) in the Czech Republic (e.g., Kukalová 1964; Kukalová-Peck \& Willmann 1990; Dostál \& Prokop 2009). Pešek (2004) provided the most comprehensive data on lithostratigraphy of this locality in Boskovice graben. The present discovery of fossil insects based on fore- and hindwings from the Early Permian of the Saar-Nahe Basin similar in venation pattern to insects known from Obora in Boskovice graben is of interest for the knowledge of the intrageneric diversity and limits between the genera in grylloblattid insects.

\section{MATERIAL AND METHODS}

The Saar-Nahe Basin is a Late Variscan intermontane basin situated in southwestern Germany and northeastern France. Its rapid subsidence and aggregation of sediments started in the Late Pennsylvanian (Namurian/Westphalian) and continued until Early Permian (Autunian) (Schäfer 2001; Rössler \& Schneider 2006). Lake Odernheim was one of larger lakes that covered almost half of the Saar-Nahe Basin area about $40 \mathrm{~km}^{2}$. Fossils preserved in black shales are known by arthropods, bivalves and mainly vertebrates such as fish and amphibians (Boy 1976, 2003). Based on the insect zonation of Schneider \& Werneburg (2006), the Odernheim black shale (Meisenheim Formation) belongs to the Spiloblattina odernheimensis zone (no. 10) (Lower Rotliegend, Early Sakmarian). The world-famous Obora insect site from Sakmarian/Early Artinskian of the Boskovice graben (Bacov horizon, Letovice Formation) belongs to the "Syscioblattan. $\mathrm{n}$. from Obora-Moravamylacris kukalovae zone" (no. 11) (Schneider \& Werneburg 2006).

The fossil specimens preserved as gently pyritized yellow imprints in black shales were observed under a stereomicroscope OLYMPUS SZX-9 in dry state and under film layer of ethyl alcohol. The venation patterns were drawn directly using a stereomicroscope with a camera lucida and finally readjusted to the photograph scales using image-editing software (Adobe Photoshop). Photographs were made using a digital camera Olympus 5050 connected to the stereomicroscope. 
We follow the wing vein nomenclature and systematics proposed by Storozhenko $(1998,2002)$.

The type material is housed at the Muséum national d'Histoire naturelle, Paris, Collection de Paléontologie (MNHN.F).

\section{ABBREVIATIONS}

Abbreviations of wing venation symbols throughout the text and the figures are given as:

AA analis anterior;

AP analis posterior vein;

$\mathrm{CuA}$ cubitus anterior;

$\mathrm{CuP} \quad$ cubitus posterior;

MA media anterior;

MP media posterior;

RA radius anterior;

$\mathrm{RP} \quad$ radius posterior;

$\mathrm{ScP}$ subcosta posterior;

$\mathrm{vb} \quad$ vein-bow.

\section{SYSTEMATIC}

Order GRYLLOBLATTIDA Walker, 1914 Clade LEMMATOPHORINA Storozhenko, 1997

Family EURYPTILONIDAE Martynov, 1940 Genus Oborella Kukalová, 1964

Blania Kukalová, 1964: 101, 102 n. syn.

\section{Oborella germanica $\mathrm{n} . \mathrm{sp}$.}

(Figs $1 ; 2$ )

MATERIAL. - Holotype: MNHN.F.A31034 (a fore- and a hindwing few millimeters apart from one another). Paratype: MNHN.F.A31035 (a fore- and a hindwing few millimeters apart from one another).

DiAGNOSIS. - 13-14 crossveins in forewing costal area, in one or two rows; RP forked; MA simple; MP forked; $\mathrm{CuA}$ with two main branches, anterior one forked and posterior one simple.

Etymology. - Named after Germania, Latin name for Germany.

TyPE LOCALITY. - Odernheim town, Saar-Nahe Basin, Rheinland-Pfalz, Germany.

TYPE STRATA. - Early Permian, Rotliegend, Meisenheim Formation, Odernheim Subformation, Odernheim lake horizon (L-O8 or M8 respectively), lacustrine black shales.
DESCRIPTION

Holotype (Figs 1A, B; 2A,B).

Forewing with costal margin slightly convex and rounded apex; originally with a pattern of coloration (see Fig. 2A, B); length of forewing fragment about $11.2 \mathrm{~mm}$, probable total length about $11.3 \mathrm{~mm}$, width in widest part $3.8 \mathrm{~mm}$; costal area $0.70 \mathrm{~mm}$ wide; ScP straight, apically deflected but reaching costal margin $3.0 \mathrm{~mm}$ from wing apex; area between costal margin and $\mathrm{ScP}$ rather broad in midwing bearing about 12 cross-veins, all simple except for five of them secondarily branched; R nearly straight, RA and $\mathrm{RP}$ separating at about $1 / 3$ of wing length from base; RA simple and straight, ending on anterior margin $2.1 \mathrm{~mm}$ from wing apex; RA and RP area irregular widest at about midwing with six cross-veins; RP bifurcated in distal third of wing, ending with two branches just above wing apex; stems of $\mathrm{M}$ and $\mathrm{R}$ very close running parallel for a short distance, $M$ divided into MA and MP $0.5 \mathrm{~mm}$ basal of separation of RA and RP; MA simple, nearly straight, ending close to wing apex; area between RP and MA with nine cross-veins; base of MP about $3.1 \mathrm{~mm}$ from wing base, bifurcated about midwing and reaching posterior wing margin with two branches; MP area rather narrow with seven crossveins between MA and MP; CuA basally strongly diverging from $\mathrm{CuP}$ towards $\mathrm{M}$, connected to it for $0.4 \mathrm{~mm}$, and with two basal branches, first distally forked again and second simple and straight; CuP simple and nearly straight; area between $\mathrm{CuA}$ and $\mathrm{CuP}$ with one row of cells (five of them being preserved).

Hindwing costo-basal part preserved, with pattern of colouration similar to that of forewing; length of fragment $7.5 \mathrm{~mm}$, width $2.9 \mathrm{~mm}$; costal area much narrower than in forewing, $0.34 \mathrm{~mm}$ wide, with nine simple crossveins; $\mathrm{ScP}$ ending on costal margin, shorter than in forewing; base of $\mathrm{RP}$ close to wing base, $1.8 \mathrm{~mm}$ apart; preserved part of RA simple and straight; basal stem of RP $4.5 \mathrm{~mm}$ long, first fork of RP preserved; six preserved crossveins between RA and RP; stem of M straight, forked into MA and MP $3.8 \mathrm{~mm}$ from wing base, well distal of base of RP; preserved part of MA simple; MP forked; basal stem of $\mathrm{Cu}$ not preserved, CuA forked, CuP simple and straight, anal veins not preserved. 

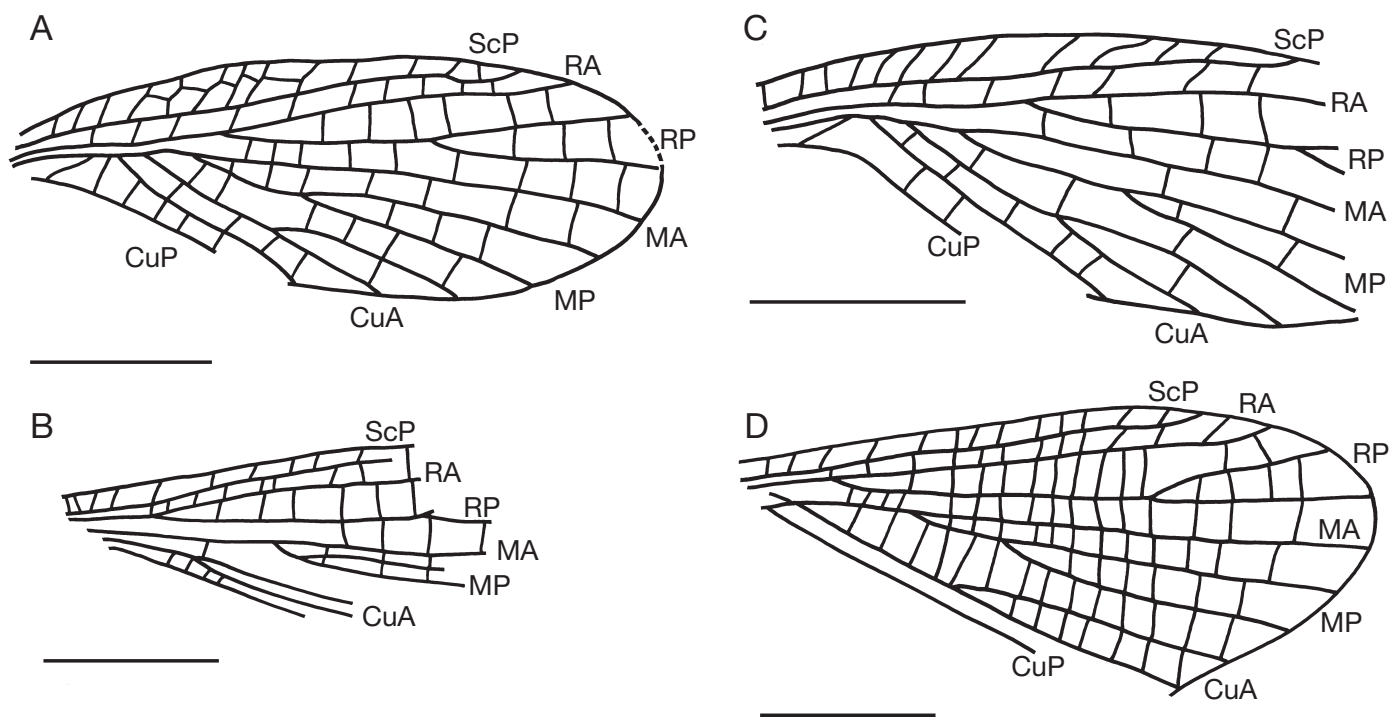

FIG 1. - Oborella germanica n. sp.: A, B, drawings of holotype fore- and a hindwing venation (MNHN.F.A31034); C, D, drawings of paratype fore- and a hind wingvenation (MNHN.F.A31035). Scale bars: $3 \mathrm{~mm}$.

\section{Paratype (Figs $1 C-D ; 2 C$ )}

Length of forewing fragment about $8.7 \mathrm{~mm}$, probable total length about $11.5 \mathrm{~mm}$, width in widest part $3.8 \mathrm{~mm}$. Forewing differing from that of holotype as follows: costal area with only one row of cells but with oblique crossveins in distal part mainly. Hindwing more complete than that of holotype, length of fragment $10.8 \mathrm{~mm}$, width $5.1 \mathrm{~mm}$, adding the following information: $\mathrm{ScP}$ ending on costal margin $3.4 \mathrm{~mm}$ from wing apex; RA with an apical short fork, ending $2.2 \mathrm{~mm}$ from wing apex; RP with two branches; MA simple, MP forked; CuA with a deep fork, basally connected to median stem; CuP simple, parallel to $\mathrm{CuA}$.

\section{DisCUSSION}

In the holotype the fore- and hindwings are very close to each other, showing that they probably correspond to the same specimen. The same situation occurs for the paratype. The great similarity in wing venation of both fore- and hindwing supports an attribution of the holotype and paratype to the same species. Following the key of Storozhenko (1998: 65-67) Oborella germanica n. sp. can be attributed to the family Euryptilonidae
Martynov, 1940 (Lemmatophorina sensu Storozhenko 1998: 81) and to the genera Blania Kukalová, 1964 and Oborella Kukalová, 1964. These genera are currently separated on the basis of the number of crossveins in forewing costal area 11-12 in Blania versus 16-19 in Oborella (Kukalová 1964). Oborella germanica n. sp. has 13-14 such crossveins but of rather different pattern in the holotype and paratype (two rows of crossveins versus one row of oblique elongate crossveins). Therefore O. germanica n. sp. makes the "link" between the two genera and can be easily separated from all previously described species of both genera on the basis of this character. We consider that the separation between Blania and Oborella no longer stands. Thus we propose to synonymize the two genera. As first revisors, we choose to consider Blania as a junior synonym of Oborella because the holotype of the type species O. matura Kukalová, 1964 is a better preserved specimen than that of Blania.

Oborella germanica n. sp. can be separated from O. matura, O. rusticana Kukalová, 1964, and $O$. inexpectata Kukalová, 1964, all described from Obora by the presence of RP ending with 

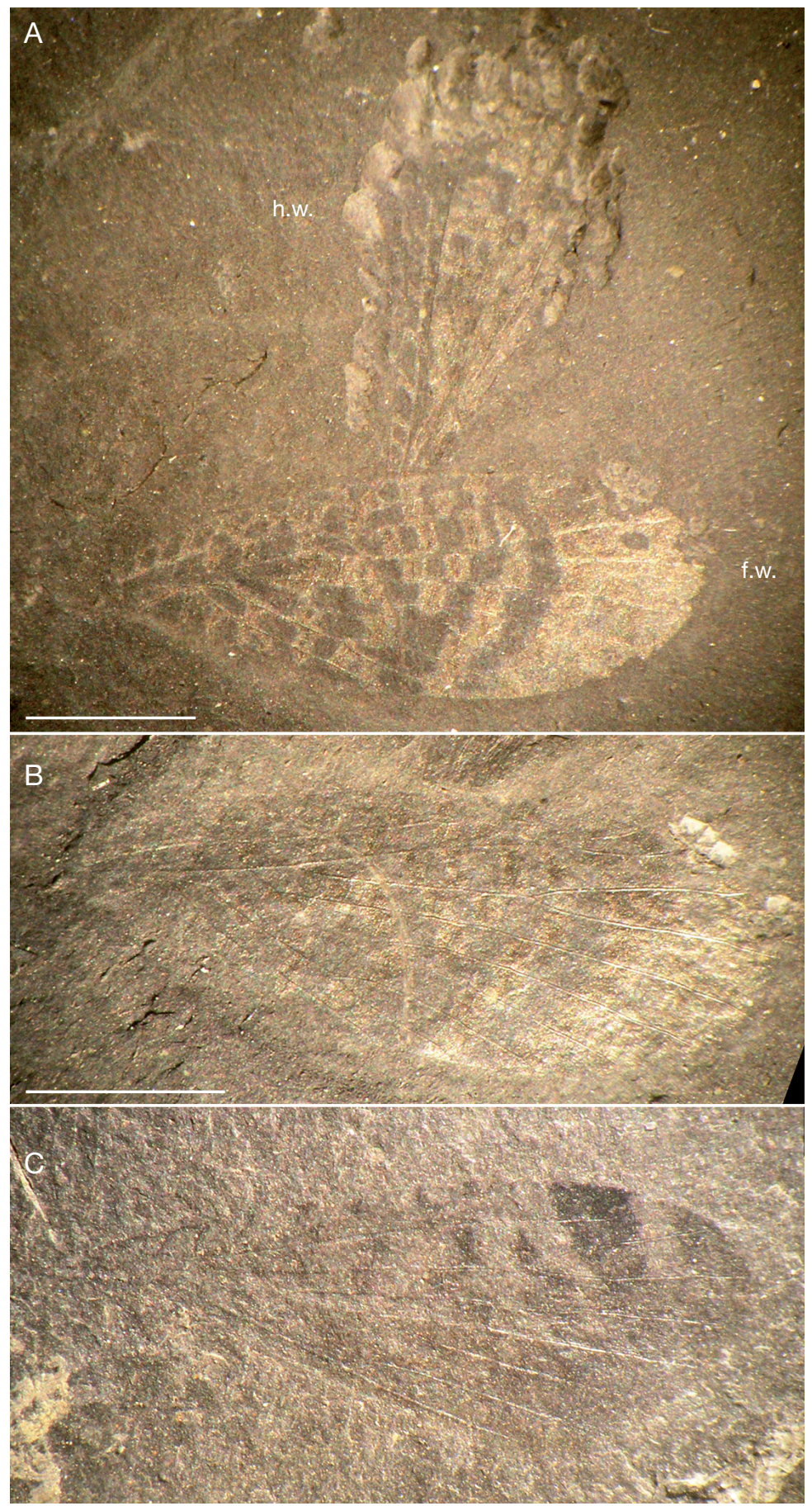

FIG 2. - Oborella germanica n. sp.: A, photograph of holotype fore- (f.w.) and hindwing (h.w.) venation (MNHN.F.A31034); B, detail photograph of holotype forewing venation (MNHN.F.A31034); C, photograph of paratype hindwing venation (MNHN.F.A31035). Scale bars: 3 mm. 
only two branches instead of being pectinated with three or more terminal branches. Furthermore, O. germanica n. sp. differs from $O$. rotunda (Kukalová, 1964) and O. oviformis (Kukalová, 1964) by the presence of MA simple instead being deeply forked. Finally O. falsa (Kukalová, 1964) differs from $O$. germanica n. sp. by well separated stem of $\mathrm{M}$ and $\mathrm{CuA}$ in basal part instead of their partial connection.

Oborella germanica n. sp. shows rather well preserved hindwings, which is of interest for the knowledge of the wing venation in Euryptilonidae. In this family, the hindwing structures are currently poorly known (Storozhenko 1998, 2002; Aristov 2002). Among the other lemmatophorine families except in Daldubidae Storozhenko, 1996, CuA is reaching median stem and fused with it for a short distance, as in O. germanica n. sp. Another interesting character is the absence of contact between RP and MA in the hindwing of $O$. germanica n. sp., unlike in Daldubidae, Atactophlebiidae, and Lemmatophoridae.

\section{Oborella brauckmanni n. sp.}

(Figs 3; 4)

MATERIAL. - Holotype MNHN.F.A31044 (two forewings superimposed).

DiAGNOSIS. - Crossveins in forewing costal area simple, short and in one row; RP forked; MA simple; MP forked; $\mathrm{CuA}$ with two main branches, both simple.

ETymology. - Named after Prof. Carsten Brauckmann, specialist on Palaeozoic insects.

TYPE LOCALITY. - Odernheim town, Saar-Nahe Basin, Rheinland-Pfalz, Germany.

Type STRATA. - Early Permian, Rotliegend, Meisenheim Formation, Odernheim Subformation, Odernheim lake horizon (L-O8 or M8 respectively), lacustrine black shales.

\section{DESCRIPTION}

Forewing with costal margin slightly convex and rounded apex; without visible pattern of colouration, maybe due to problem of preservation, also some crossveins hardly visible; length of preserved part of wing $7.0 \mathrm{~mm}$, max. width $2.8 \mathrm{~mm}$; ScP straight, apically deflected but reaching costal margin $3.1 \mathrm{~mm}$ from wing apex; area between costal margin and $\mathrm{ScP}$ rather broad in midwing with nine preserved simple cross-veins; R nearly straight, RA and RP separating at about 3.0 of wing length from base; simple RA nearly straight, and ending on anterior margin $0.8 \mathrm{~mm}$ from wing apex; RA and RP area irregular widest at about midwing; RP bifurcated in distal third of wing, ending with two branches just above wing apex; $\mathrm{M}$ divided into MA and MP about $2.2 \mathrm{~mm}$ basal of separation of RA and RP; MA simple, nearly straight, ending close to wing apex; area between $\mathrm{RP}$ and MA with cross-veins; MP reaching posterior wing margin with two branches; MP area rather narrow; $\mathrm{CuA}$ with two basal branches, both simple and straight; $\mathrm{CuP}$ and anal area not preserved.

\section{DISCUSSION}

This fossil looks very similar to Oborella germanica n. sp. from the same outcrop and level. The more accurate difference between $O$. brauckman$n i$ n. sp. and the other species of Oborella is the anterior branch of $\mathrm{CuA}$ simple instead of being deeply forked. Other differences with O. germanica n. sp. are: fork of MP at the level of base of $\mathrm{RP}$ instead of being in a more distal position, and apex of $\mathrm{ScP}$ more distant from apex of RA than in O. germanica n. sp.

\section{Clade BLATTINOPSEIDA Bolton, 1925}

Family BlatTinOPSIDAE Bolton, 1925

$$
\text { gen. et sp. indet. }
$$

(Figs 5-8)

MATERIAL. - MNHN.F.A31047 (antero-median part of a forewing); MNHN.F.A31048 (anterior part of a forewing).

TYPE LOCALITY. - Odernheim town, Saar-Nahe Basin, Rheinland-Pfalz, Germany.

TyPe STRATA. - Early Permian, Rotliegend, Meisenheim Formation, Odernheim Subformation, Odernheim lake horizon (L-O8 or M8 respectively), lacustrine black shales. 


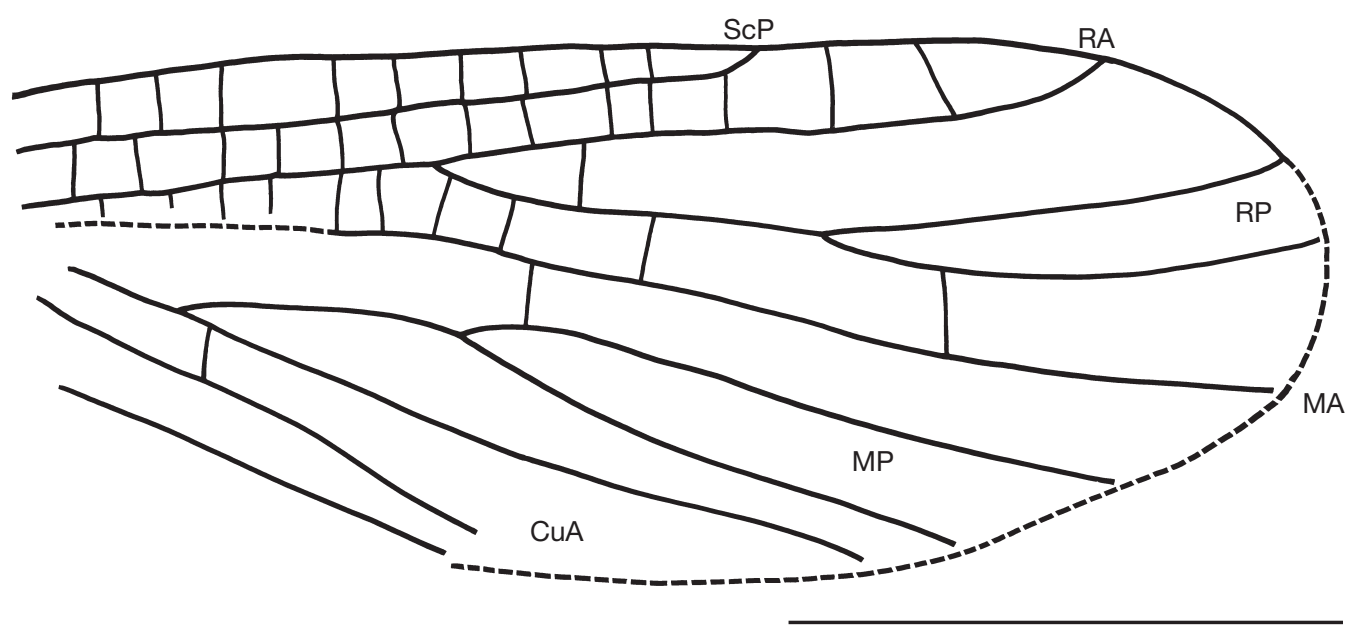

FIG. 3. - Oborella brauckmanni n. sp., drawing of forewing venation (holotype MNHN.F.A31044). Scale bar: 3 mm.

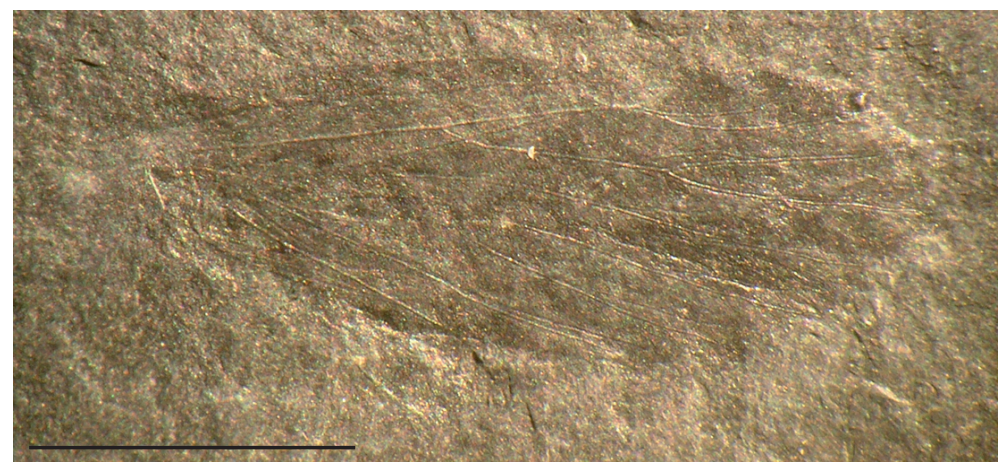

FIG. 4. - Oborella brauckmanni n. sp., photograph of forewing venation (holotype MNHN.F.A31044). Scale bar: $3 \mathrm{~mm}$.

\section{DESCRIPTIONS}

\section{Specimen MNHN.F.A31047 (Figs 5; 6)}

Length of fragment $8.0 \mathrm{~mm}$, width $5.6 \mathrm{~mm}$; costal area $0.9 \mathrm{~mm}$ wide; area between $\mathrm{ScP}$ and RA $0.83 \mathrm{~mm}$ wide; RA simple; base of RP $3.7 \mathrm{~mm}$ from wing base; stem of RP very short, RP with a least five branches; $M$ with only one stem emerging from Radius near wing base, and at least two distal branches; a strong oblique crossvein between $\mathrm{M}$ and $\mathrm{CuA}$; $\mathrm{CuA}$ with at least three distal branches; $\mathrm{CuP}$ simple; area between $\mathrm{CuA}$ and $\mathrm{CuP}$ very broad, with four rows of cells.
Specimen MNHN.F.A31048 (Figs 7; 8)

Length of fragment $15.5 \mathrm{~mm}$, width $4.6 \mathrm{~mm}$; costal area $0.98 \mathrm{~mm}$ wide; area between $\mathrm{ScP}$ and RA $1.1 \mathrm{~mm}$ wide; RA simple; base of RP $4.4 \mathrm{~mm}$ from wing base; stem of RP very long, $1.7 \mathrm{~mm}$ long, RP with a least about 11 branches, presence of longitudinal furrows between branches of RP; $M$ with two stems emerging from radius, one near wing base and second near base of RP; a strong oblique crossvein between $\mathrm{M}$ and $\mathrm{CuA}$; area between $\mathrm{CuA}$ and CuP probable broad. 


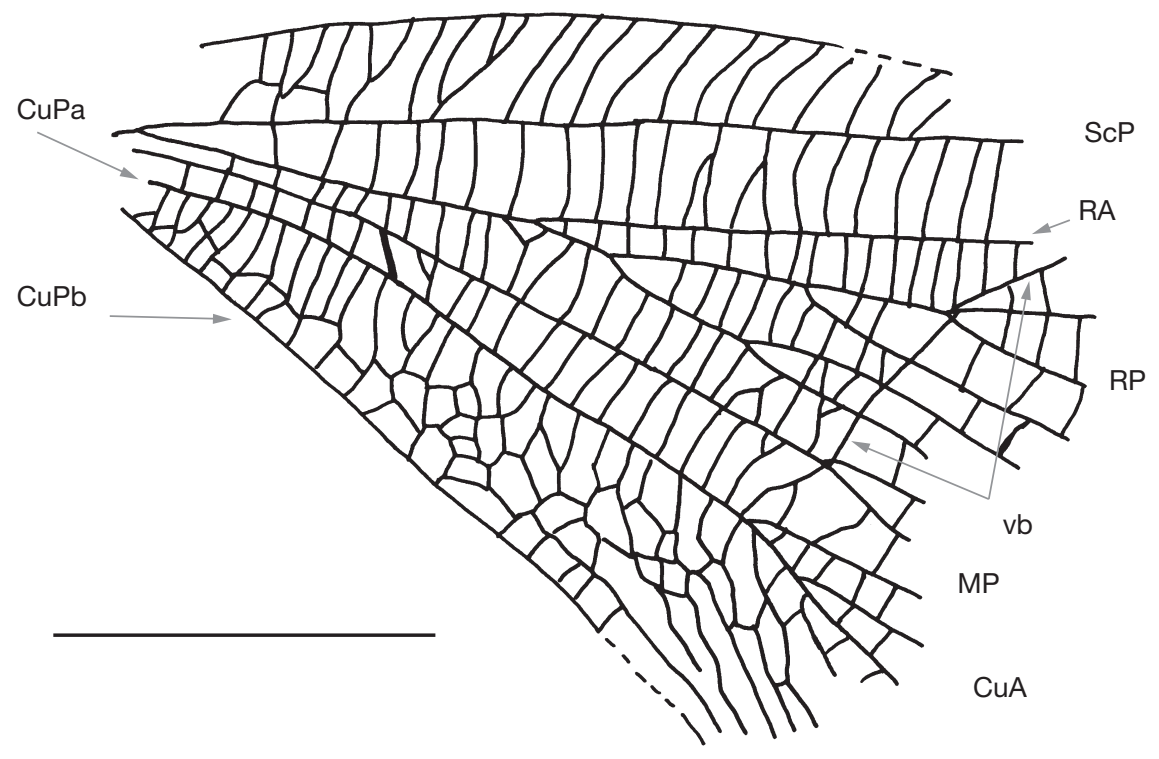

FIG. 5. - Blattinopsidae Bolton, 1925, gen. et sp. indet., drawing of forewing venation (MNHN.F.A31047). Scale bar: 3 mm.

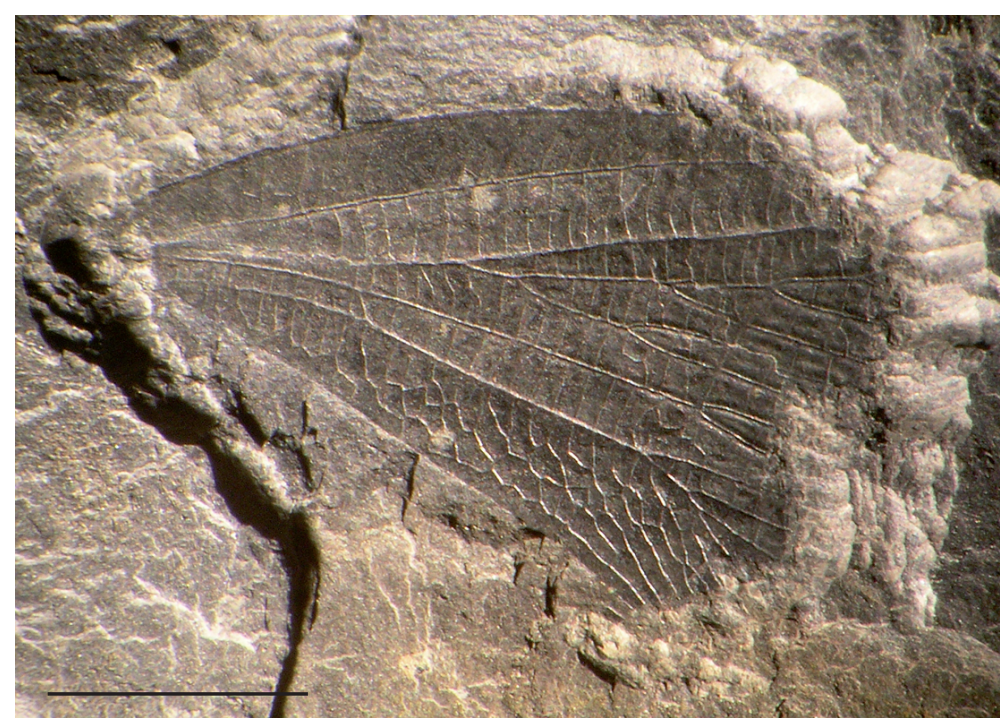

FIG. 6. - Blattinopsidae Bolton, 1925, gen. et sp. indet., photograph of forewing venation (MNHN.F.A31047). Scale bar: 3 mm.

\section{DisCUSSION}

These two forewing fragments correspond to Blattinopsidae for the broad area between ScP and R; $\mathrm{RP}$ with many posterior branches, presence of a vein-bow (visible in specimen MNHN.F.A31047);
$\mathrm{CuA}$ closely parallel with posterior branch of $\mathrm{M}$; a distinct brace between $\mathrm{CuA}$ and $\mathrm{M}$ (Béthoux \& Nel 2002). All the characters of the wing venation of specimen MNHN.F.A31048 are typical of blattinopsids of the two genera Blattinopsis Giebel, 


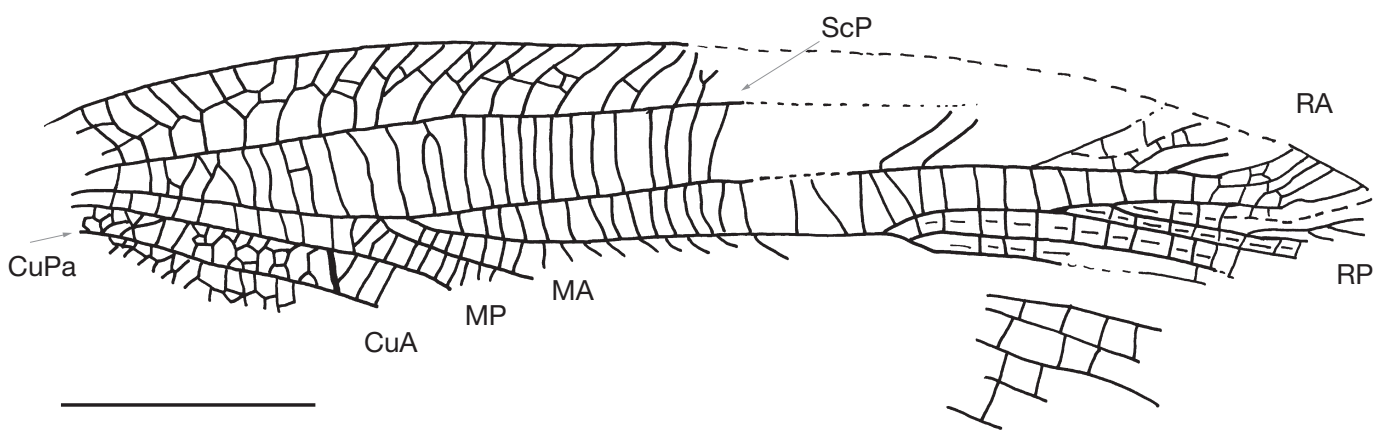

FlG. 7. - Blattinopsidae Bolton, 1925, gen. et sp. indet., drawing of forewing venation (MNHN.F.A31048). Scale bar: 3 mm.

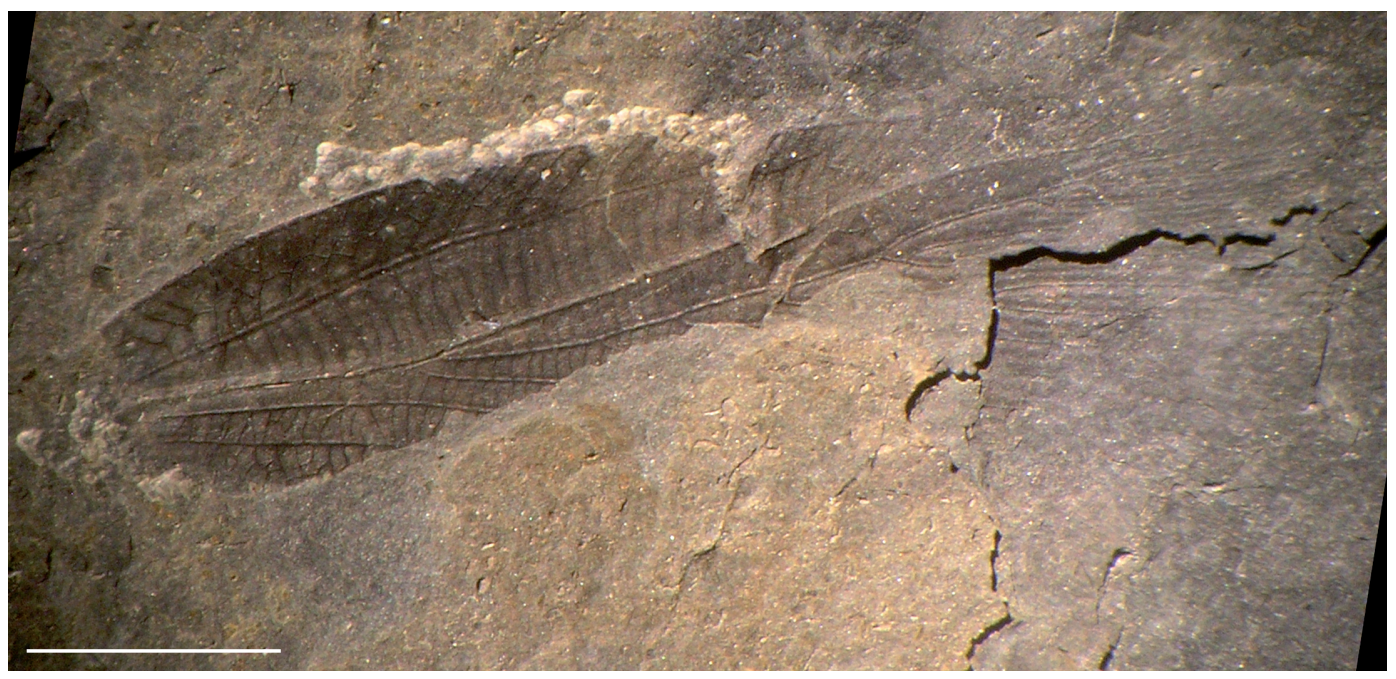

FIG. 8. - Blattinopsidae Bolton, 1925, gen. et sp. indet., photograph of forewing venation (MNHN.F.A31048). Scale bar: 3 mm.

1867 and Glaphyrophlebia Handlirsch, 1906 for the presence of only one branch of $\mathrm{M}$ emerging from $\mathrm{R}$ and broad area between ScP and RA. The differences between these two genera are weak and few and concern the area between the branches of RP, i.e. presence versus absence of longitudinal furrows between branches of RP. These are not visible in specimen MNHN.F.A31047. Thus it is not possible to prefer one of these genera for this fossil.

Specimen MNHN.F.A31048 has such furrows between the branches of RP, thus it could be related to Glaphyrophlebia. It has two branches of media emerging separately from radial stem, but this character is present in other representatives of
Blattinopsis and other genera (Hörnschemeyer \& Stapf 2001). Nevertheless, it has a very particular structure, unique among the Blattinopsidae, i.e. a very long stem of RP. This would support an attribution to a new species of Glaphyrophlebia, but we prefer not to name it for its very incomplete state of preservation.

In addition two species based on fragmentary wings (Blattinopsis arnhardi Müller, 1977, Blattinopsis tardefurcata Müller, 1977) were described from the Lower Rotliegend of the locality SperbersbachSchmücke (near Oberhof village, Suhl district) in the Thuringian Forest Mts (Müller 1977). Blattinopsis arnhardi differs from MNHN.F.A31047 in the fork 
of MP close to base of RP. Blattinopsis tardefurcata differs from it in the presence of numerous small cells in area between $\mathrm{CuA}$ and $\mathrm{CuPb}$.

\section{CONCLUSION}

New insect specimens are described from Early Permian deposits of Odernheim (Saar-Nahe Basin, Rheinland-Pfalz, Germany) and attributed to Euryptilonidae (Grylloblattida) and Blattinopsidae (possible stem group of Dictyoptera). Oborella germanica n. sp. is based on fore- and hindwing venation pointing out difficulties of generic separation between Blania and Oborella. Therefore we consider Blania as a junior synonym of Oborella because the holotype of the type species O. matura Kukalová, 1964 is a better preserved specimen than that of Blania. We also describe another species $O$. brauckmanni n. sp. and two representatives of Blattinopsidae are also described but not named due to their incomplete state of preservation, although one is related to Glaphyrophlebia and could well correspond to a new species for its very long stem of RP.

The diverse entomofauna of Obora compared to the nearly exclusive blattid-dominated entomofauna of the Early Permian in the Boskovice graben below the Obora horizon and compared to the equally blattid-dominated entomofaunas of the other European basins was, with the exception of the Lodève Basin, so far a mystery (e.g., Schneider 1984a, b; Béthoux et al. 2007). The discovery of grylloblattids in the Upper Lower Rotliegend of the Saar-Nahe Basin, taxonomi$\mathrm{cal}$ and in age very close to Obora, could serve as a key for increasing understanding of the dynamics of entomofaunas in relation to climatic and environmental changes during the Permian (Rössler \& Schneider 2006).

\section{Acknowledgements}

Authors are grateful for valuable comments and suggestions considering mainly Permian stratigraphy and insect biozonation to R. Beckemeyer and to an anonymous referee. The first author
(JP) acknowledges the research support from the Grant Agency of the Czech Republic (no. P210/10/0633), and from the Ministry of Schools (MSM 0021620828).

\section{REFERENCES}

ARISTOV D. S. 2002. - New euryptilonids (Insecta: Grylloblattida; Euryptilonidae) from the Lower Permian of the Urals (Russia). Neues Jahrbuch für Geologie und Paläontologie, Monatshefte (4): 252-256.

BéTHOux O. \& Nel A. 2002. - Venation pattern and revision of Orthoptera sensu nov. and sister groups. Phylogeny of Palaeozoic and Mesozoic Orthoptera sensu nov. Zootaxa 96: 1-88.

Béthoux O., Nel A., Schneider J. W. \& Gand G. 2007. - Lodetiella magnifica nov. gen. and nov. sp. (Insecta: Palaeodictyoptera; Permian; Salagou Formation, France), a new edge in wing morphology of palaeopterous insects. Geobios 40: 181-189

BoY J. A. 1976. — Überblick über die Fauna des saarpfälzischen Rotliegenden (Unter-Perm). Mainzer geowissenschaftliche Mitteilungen 5: 13-85.

BoY J. A. 2003. — Exkursion 2: Paläoökologie permokarbonischer Seen. Terra Nostra 5: 188-215.

DostÁL O. \& PROKOP J. 2009. - New fossil insects from the Lower Permian of Boskovice Basin in southern Moravia (Diaphanopterodea: Martynoviidae). Geobios 42 (4): 495-502.

HÖRNSCHEMEYER T. \& STAPF H. 2001. - Review of Blattinopsidae (Prothortoptera) with description of new species from the Lower Permian of Niedermoschel (Germany). Neues Jahrbuch für Geologie und Paläontologie, Abhandlungen 221 (1): 81-109.

KukAlOVÁ J. 1964. - Permian insects of Moravia. 2. Liomopteridae. Sborník Geologických Vëd, Paleontologie 3: 39-118.

Kukalová-PeCK J. \& Willmann R. 1990. - Lower Permian "mecopteroid-like" insects from central Europe (Insecta, Endopterygota). Canadian Journal of Earth Sciences 27: 459-468.

Müller A. H. 1977. - Zur Entomofauna des Permokarbon: 2. Über einige Blattinopsidae (Protorthoptera) aus dem Unterrotliegend (Unterperm, Autun) von Mitteleuropa. Zeitschrift für geologische Wissenschaften 5: 1029-1051.

PEŠEK J. 2004. - Late Paleozoic limnic basins and coal deposits of the Czech Republic. Folia Musei Rerum Naturalium Bohemiae Occidentalis, Geologica, Editio Specialis 1: 1-188.

RÖsSler M. \& SChNeider J. W. 2006. - PermoCarboniferous climate: Early Pennsylvanian to Late Permian climate development of central Europe in a regional and global context, in LUCAS S., CASSINIS 
G. \& SCHneider J. W. (eds), Non-marine Permian biostratigraphy and biochronology. The Geological Society of London, Special Publication 265: 95-136.

SCHÄFER A. 2001. - Stratigraphical constraints on molasse depositional systems in the Permo-Carboniferous SaarNahe Basin, Germany. Natura Bresciana, Annali del Museo Civico di Scienze Naturale, Monografia 25: 213-219.

SCHNEIDER J. 1984a. - Die Blattodea (Insecta) des Paläozoikums, 2: Morphogenese der Flügelstrukturen und Phylogenie. Freiberger Forschungshefte (C) 391: 5-34.

SCHNEIDER J. 1984b. - Zur Entomofauna des Jungpaläozoikums der Boskovicer Furche (CSSR), Teil 2. Phyloblattidae (Insecta, Blattodea). Freiberger Forschungshefte (C) 395: 19-37.

SCHNEIDER J. \& WeRnEbURG R. 2006. - Insect biostratigraphy of the Euramerican continental Late Pennsylvanian and Early Permian, in LuCAS S. G.,
CAssinis G. \& SCHneider J. W. (eds), Non-Marine Permian biostratigraphy and biochronology. The Geological Society of London, Special Publication 265: 325-336.

STOROZHENKO S. Y. 1998. - Sistematika, filogeniya $i$ evolyutsiya grilloblattidovykh nasekomykh (Insecta: Grylloblattida) [Systematics, phylogeny and evolution of the grylloblattids (Insecta: Grylloblattida)]. Dal'nauka, Vladivostok: 1-207.

Storozhenko S. Y. 2002. - Chapter 2.2.2.2.1. Order Grylloblattida Walker, 1914 (= Notoptera Crampton, 1915, = Grylloblattodea Brues et Melander, 1932, + Protorthoptera Handlirsch, 1906, = Paraplecoptera Martynov, 1925, + Protoperlaria Tillyard, 1928), in Rasnitsyn A. P. \& Quicke D. L. J. (eds), History of Insects. Kluwer Academic Publishers, Dordrecht, Boston, London: $x i+517$ p.

Submitted on 9 November 2009; accepted on 10 January 2011. 
